\title{
High concentrations of natural rubber latex allergens in gloves used by laboratory health personnel in South Africa
}

M E Ratshikhopha, ${ }^{1}$ MSc (Med); T S Singh, ${ }^{1,2} \mathrm{PhD} ;$ D Jones, ${ }^{1} \mathrm{MPH} ; \mathbf{M}$ F Jeebhay, ${ }^{3} \mathrm{MB}$ ChB, MPhil (Epi), MPH, PhD; A L Lopata, ${ }^{4,5} \mathrm{PhD}$

${ }^{1}$ National Institute for Occupational Health, National Health Laboratory Service, Johannesburg, South Africa

${ }^{2}$ Department of Clinical Microbiology and Infectious Diseases, School of Pathology, University of the Witwatersrand, Johannesburg, South Africa

${ }^{3}$ Centre for Occupational and Environmental Health Research, University of Cape Town, South Africa

${ }^{4}$ Division of Tropical Health and Medicine and Centre for Biodiscovery and Molecular Development of Therapeutics, James Cook University,

Townsville, Australia

${ }^{5}$ Division of Immunology and Institute of Infectious Disease and Molecular Medicine, University of Cape Town, South Africa

Corresponding author: M E Ratshikhopha (edith.ratshikhopha@nioh.nhls.ac.za)

Introduction. Gloves made of natural rubber latex (NRL) are commonly used by healthcare workers because of their good qualities. However, allergic reactions to latex allergens are still commonly reported.

Objective. To measure the concentrations of $\mathrm{Hev} \mathrm{b} \mathrm{1,} \mathrm{Hev} \mathrm{b} \mathrm{3,} \mathrm{Hev} \mathrm{b} 5$ and $\mathrm{Hev}$ b 6.02 allergens in gloves used by a large laboratory service in South Africa.

Methods. NRL gloves as well as non-latex gloves supplied by various suppliers that were used by the laboratory personnel during the period June 2009 - May 2010 were obtained from various suppliers on the vendor list. Proteins were extracted from the gloves and Hev b 1, Hev b 3 , Hev b 5 and Hev b 6.02 allergens were quantified using the FITkit assay.

Results. Twenty NRL gloves from 13 different brands were analysed. Only four (20\%) of the 20 NRL gloves analysed had a total allergen content $<0.15 \mu \mathrm{g} / \mathrm{g}$, the suggested threshold limit for low allergenicity for the sum of these four allergens.

Conclusion. This study demonstrated that a very low proportion of gloves tested had a total allergen content below the threshold for low allergenicity.

S Afr Med J 2015;105(1):43-46. DOI:10.7196/SAMJ.8082 


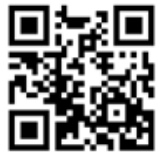

While natural rubber latex (NRL) gloves generally offer effective barrier protection against contact with body fluids, micro-organisms and solvents, ${ }^{[1]}$ adverse reactions have been associated with their use. These include immunoglobulin E-mediated allergic reactions and irritant and allergic contact dermatitis. ${ }^{[2]}$

Allergic reactions to NRL gloves are attributed to a very small fraction of residual extractable proteins containing allergens. ${ }^{[3]}$ Significant differences in allergen levels have been shown in different brands of gloves. ${ }^{[4]}$ Thirteen different hevein latex proteins have been recognised as allergens by the Allergen Nomenclature Subcommittee of the World Health Organization/International Union of Immunological Societies. ${ }^{[5]}$

Latex allergenicity has been determined by measuring the levels of the clinically relevant hevein allergens (Hev b 1, Hev b 3, Hev b 5 and Hev b 6.02) in the gloves used by healthcare workers (HCWs). ${ }^{[6]}$ In that study, the sum of the concentrations of the four allergens quantified, when set at $0.15 \mu \mathrm{g} / \mathrm{g}$, discriminated 'lowallergenic' ( $<10$ allergy units (AUs)/ml) from 'moderate- to highallergenic' ( $\geq 10$ AUs/ml) gloves. ${ }^{[6]}$ A South African (SA) study quantified Hev b 1, Hev b 3, Hev b 5 and Hev b 6.02 in gloves used in dental schools and found the levels to be above the suggested recommendation. ${ }^{[7]}$ Previous studies have shown a reduction in latex allergy when workers were exposed exclusively to powderfree low-protein latex gloves. ${ }^{[8-9]}$

\section{Objective}

To measure the concentrations of Hev b1, Hev b 3, Hev b 5 and Hev b 6.02 latex-specific allergens in gloves being used by a large laboratory service provider, and to determine the allergen levels of gloves to be purchased from prospective suppliers of new gloves prior to their purchase.

\section{Materials and methods}

The procurement of NRL gloves by most large health service providers is based on cost-effectiveness and meeting criteria of the South African Bureau of Standards guidelines (SANS11193-1:2010) for latex gloves. All goods procured by the laboratory service provider are registered on the organisation's procurement system database. A search of the procurement system database using the word 'gloves' was conducted on 3 June 2009 and repeated on 6 May 2010. A list of NRL and non-latex gloves that were active on the system, with accompanying information on the supplier, glove type, glove size, glove cost and brand, was compiled. The laboratory analysis was performed at the National Institute for Occupational Health, Johannesburg, SA. After the initial evaluation of the allergen content of gloves used in the organisation, criteria were set and tender specifications developed and advertised in the local newspaper. Only companies that met the criteria were asked to submit samples of gloves that they intended to supply for confirmatory testing.

Extraction of latex proteins was done as described by Mabe et al. ${ }^{[7]}$ The FITkit (Icosagen AS, Estonia) was used to quantify $\mathrm{Hev}$ b 1, Hev b 3, Hev b 5 and Hev b 6.02 allergens according to the manufacturer's instructions. Briefly, precoated Hev b 1, Hev b 3, Hev b 5 and Hev b 6.02 monoclonal antibody microtitre plates were used. The extracted sample, controls and standards were added to wells and incubated. All the measurements were done in duplicate. The plates were washed, horseradish peroxidase (HRP)-labelled specific monoclonal antibody was added to each well, and the plates were incubated at room temperature. After washing the plates, HRP substrate was added to all wells and the plate was incubated at room temperature again. Absorbance was measured at $405 \mathrm{~nm}$ and the concentrations were reported in $\mu \mathrm{g} / \mathrm{L}$, which was converted to $\mu \mathrm{g} / \mathrm{g}$ of glove. STATA 9 software (StataCorp 1984 - 2007, USA) was used to analyse the data. Non-parametric tests were applied because the data were not normally distributed.

\section{Results}

Twenty NRL glove samples, comprising 13 brands, were analysed. The types included 14 examination gloves, 5 surgical gloves and 1 household glove; 14 of the gloves were non-powdered and 6 were powdered (Table 1). Only 4 of the 20 NRL gloves analysed had a total allergen content (sum of Hev b 1, Hev b 3, Hev 5 and Hev b 6.02 concentrations) $<0.15 \mu \mathrm{g} / \mathrm{g}$, which has been suggested as the threshold limit for low allergenicity for the sum of the four allergens. ${ }^{[6]}$ These included the brand $\mathrm{K}$ non-sterile examination glove, brand $\mathrm{C}$ powder-free surgical glove, brand $\mathrm{F}$ 'high-risk' examination glove and brand A surgical glove. There were differences in concentrations of allergens between different types of gloves of the same brand. The brand $\mathrm{C}$ powder-free glove had a total allergen content $<0.15 \mu \mathrm{g} / \mathrm{g}$, whereas the powered glove had a content $>0.15 \mu \mathrm{g} / \mathrm{g}$. Of the two types of brand F gloves, the one labelled 'high risk' had a total allergen content $<0.15 \mu \mathrm{g} / \mathrm{g}$ and the other one a total allergen content $>0.15 \mu \mathrm{g} / \mathrm{g}$. The concentrations of the brand $\mathrm{K}$ gloves also differed (Table 1 ). The non-sterile glove had a total allergen content $<0.15 \mu \mathrm{g} / \mathrm{g}$, while the sterile glove had a total allergen content $>0.15 \mu \mathrm{g} / \mathrm{g}$.

The price of latex gloves ranged from R0.26 to R11.30 per pair in January 2011. No correlation was found between prices and the total allergen levels $\left(r_{s}-0.2024 ; p>0.05\right)$. However, it is worth noting that the cheapest glove had the highest content of Hev b allergens, and that one of the gloves with a total allergen content below the recommended cut-off was the most expensive.

The mean (standard deviation) total allergen content for powdered gloves was $21.86(5.63) \mu \mathrm{g} / \mathrm{g}$, higher than the average for the nonpowdered gloves of $14.22(6.29) \mu \mathrm{g} / \mathrm{g}$. However, the difference was not statistically significant $(p>0.05)$. There was also no significant difference between the allergen concentrations of surgical and examination gloves, although the numbers were too small to make a valid conclusion.

The initial testing of gloves in this study provided the impetus for requesting potential glove suppliers to have their gloves tested during the tender selection process. Of 27 companies that submitted a tender bid, only 11 met the criteria of the tender specifications. Five NRL glove brands were supplied for testing. The total allergen levels were $<0.15 \mu \mathrm{g} / \mathrm{g}$ in three of the brands tested. These included brand $\mathrm{F}$ gloves and two other brands that were not among those tested in the initial analysis.

\section{Discussion}

Only $20 \%$ of the NRL gloves tested had a total allergen content below the suggested threshold for low allergenicity. The findings of this study are very similar to those previously reported on glove use by dental HCWs, ${ }^{[7]}$ which showed that all the glove brands used in SA dental schools that were tested had concentrations above the threshold of $0.15 \mu \mathrm{g} / \mathrm{g}$ for the sum of four allergens tested. Three of the six brands tested in the dental study were also tested in the present study, and the results were similar. Both the current study and the dental study highlight the inferior quality of gloves being used in healthcare facilities. This situation may be very common in the healthcare setting in SA, and indeed in other African countries. It is therefore important to educate managers and procurement officers about the test available to assess the quality and latex concentration of gloves. 
Table 1. Concentration of latex allergens* of NRL glove brands used by a large laboratory service provider (results presented from lowest to highest concentration)

\begin{tabular}{|c|c|c|c|c|c|c|c|}
\hline Brand & Type & Powdered & Hev b $1(\mu \mathrm{g} / \mathrm{g})$ & Hev b $3(\mu \mathrm{g} / \mathrm{g})$ & Hev b $5(\mu \mathrm{g} / \mathrm{g})$ & Hev b $6.02(\mu \mathrm{g} / \mathrm{g})$ & Total allergen $^{\dagger}(\mu \mathrm{g} / \mathrm{g})$ \\
\hline Brand K non-sterile & Exam & No & 0 & 0 & 0 & 0 & $<0.15$ \\
\hline Brand C & Surgical & No & 0 & 0 & 0.03 & 0.03 & $<0.15$ \\
\hline Brand F 'high risk' & Exam & No & 0 & 0.07 & 0 & 0 & $<0.15$ \\
\hline Brand A & Surgical & No & 0 & 0.14 & 0 & 0 & $<0.15$ \\
\hline Brand $\mathrm{E}$ & Exam & No & 0 & 0.75 & 0.19 & 0.20 & 1.14 \\
\hline Brand D & Exam & No & 0 & 0.65 & 0.11 & 0.45 & 1.21 \\
\hline Brand K sterile & Exam & No & 0.66 & 0.91 & 0.11 & 0.19 & 1.88 \\
\hline Brand C & Surgical & Yes & 0.08 & 0.01 & 0.44 & 1.57 & 2.10 \\
\hline Brand F & Exam & No & 0.27 & 2.29 & 0.19 & 0.36 & 3.12 \\
\hline Brand G & Exam & No & 1.05 & 5.00 & 0.27 & 0 & 6.32 \\
\hline Brand I & Household & No & 0.14 & 0.58 & 10.19 & 2.06 & 12.97 \\
\hline Brand J & Surgical & Yes & 0 & 0.12 & 13.22 & 1.75 & 15.09 \\
\hline Brand $\mathrm{M}$ & Exam & No & 0 & 3.66 & 6.00 & 7.32 & 16.99 \\
\hline Brand D & Exam & Yes & 3.72 & 5.00 & 4.77 & 3.72 & 17.21 \\
\hline Brand B & Surgical & Yes & 0 & 0.16 & 0.16 & 22.55 & 22.87 \\
\hline Brand $\mathrm{M}$ & Exam & No & 0.11 & 3.70 & 15.03 & 13.32 & 32.16 \\
\hline Brand G & Exam & Yes & 0.21 & 0.68 & 18.14 & 13.57 & 32.61 \\
\hline Brand $\mathrm{H}$ & Exam & No & 0.000 & 0.00 & 8.71 & 30.84 & 39.55 \\
\hline Brand D & Exam & Yes & 2.04 & 2.69 & 20.70 & 15.79 & 41.22 \\
\hline Brand L & Exam & No & 0.33 & 1.42 & 41.67 & 39.77 & 83.18 \\
\hline
\end{tabular}

Our findings have relevance to the organisational goal of reducing exposure to latex in the workplace. Apart from the widespread move from a powdered to a powder-free glove policy in response to scientific evidence identifying cornstarch powder as the main agent responsible for the development of latex sensitisation and allergy in exposed HCWs, ${ }^{[9]}$ gloves with low latex allergen concentrations can further reduce latex allergy by limiting cutaneous exposure and dose. Laboratory studies have demonstrated that as much as $2.2 \%$ of latex allergen protein can penetrate intact skin within 24 hours of exposure. In addition, penetration of allergens through compromised skin barriers can increase by 50 -fold. ${ }^{[10]}$

In the light of these findings, recommendations were made to the procurement division of the organisation for drafting the criteria for the tender process for potential glove tender bidders. These included suggestions that all gloves supplied to the organisation must be certified with the South Africa Bureau of Standards or other international bodies to ensure an acceptable quality level. In addition, suppliers of NRL gloves were required to submit a laboratory report showing concentrations of latex-specific proteins. Glove suppliers that met the tender criteria were also required to submit a batch of the gloves that they intended to supply for confirmatory analysis of latex allergen levels. In these cases, the total allergen concentrations were $<0.15 \mu \mathrm{g} / \mathrm{g}$ in three of the five NRL glove brands tested. One of them, brand $\mathrm{F}$, had concentrations $<0.15 \mu \mathrm{g} / \mathrm{g}$ in the first and second rounds of testing. Two other brands, tested in the second round only, also had concentrations $<0.15 \mu \mathrm{g} / \mathrm{g}$.

This study has demonstrated that detailed allergen analysis of gloves conventionally accepted for 'safe' use is an important means of reducing latex exposure. It is envisaged that this strategy will reduce the risk of sensitisation and development of allergy in sensitised individuals, as previous studies have shown that using NRL gloves with a low allergen content reduces the concentrations of allergens and the number of new cases of allergy. ${ }^{[1]}$ Various studies have also reported latex proteins to be higher in powdered than in nonpowdered gloves, ${ }^{[7,12]}$ and in the present study the total allergen content of the four Hev b allergens was $>0.15 \mu \mathrm{g} / \mathrm{g}$ in all the powdered gloves tested. This is a reason to recommend powder-free gloves. Although substitution of powdered with powder-free latex gloves has been shown to reduce latex allergy and associated symptoms, cutaneous exposure remains a concern. ${ }^{[10]}$ The benefit of NRL gloves can still be retained by purchasing low-allergen and powder-free gloves. ${ }^{[13]}$ Since the current study did not show a correlation between total allergen content and price of gloves, it is clear that gloves with low concentrations of allergens can be purchased without increasing the costs to the procuring organisation.

\section{Conclusion}

The allergen content of different types of NRL gloves varies greatly. This study demonstrated that a very small proportion of gloves tested $(20 \%)$ had a total allergen content below the suggested threshold for low allergenicity. Identification of latex gloves with a low content of allergens can contribute towards minimising the risk of sensitisation and allergic reactions to latex. Ultimately, in all healthcare settings the health and wellbeing of staff who are required to wear gloves rests with the relevant purchasing authorities. The absence of a correlation between latex allergen content and price of gloves suggests that costeffective purchasing of non-powdered, low protein latex gloves is possible. 


\section{References}

1. Rego A, Roley L. In-use barrier integrity of gloves: Latex and nitrile superior to vinyl. Am J Infect Control 1999;27(5):405-410. [http://dx.doi.org/10.1016/S0196-6553(99)70006-4]

2. Cohen DE, Scheman A, Stewart L, et al. American Academy of Dermatology's position paper on latex allergy. J Am Acad Dermatol 1998;39(1):98-106. [http://dx.doi.org/10.1016/S0190-9622(98)70406-2] 3. Reddy S. Latex allergy. Am Fam Physician 1998;57(1):93-102.

4. Palosuo T, Alenius H, Turjanmaa K. Quantitation of latex allergens: Methods. 2002;27(1):52-58. [http:// dx.doi.org/10.1016/S1046-2023(02)00051-8]

5. Wagner S, Breiteneder H. Hevea brasiliensis latex allergens: Current panel and clinical relevance. Int Arch Allergy Immunol 2005;136(1):90-97. [http://dx.doi.org/10.1159/000082938]

quantity of four major

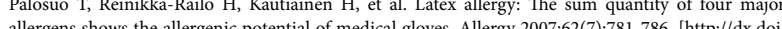
allergens shows the allergenc potential of ming org/10.1111/.1398-9995.2007.01411.x]

7. Mabe DO, Singh TS, Bello B, Jeebhay MF, Lopata AL, Wadee A. Allergenicity of latex rubber products used in South African dental schools. S Afr Med J 2009;99(9):672-674.

. Tarlo SM, Easty A, Eubanks K, et al. Outcomes of a natural rubber latex control program in an Ontario teaching hospital. J Allergy Clin Immunol 2001;108(4):628-633. [http://dx.doi.org/10.1067/ mai.2001.118792]
9. Jackson EM, Arnette JA, Martin ML, Tahir WM, Frost-Arner L, Edlich RF. A global inventory of hospitals using powder-free gloves: A search for principled medical leadership. J Emerg Med 2000;18(2):241-246. [http://dx.doi.org/10.1016/S0736-4679(99)00202-4]

10. Hayes BB, Afshari A, Millecchia L, Willard PA, Povoski SP, Meade BJ. Evaluation of percutaneous penetration of natural rubber latex proteins. Toxicol Sci 2000;56(2):262-270. [http://dx.doi. org/10.1093/toxsci/56.2.262]

11. Hunt LW, Kelkar P, Reed CE, Yunginger JW. Management of occupational allergy to natural rubber latex in a medical center. The importance of quantitative latex allergen measurement and objective followup. J Allergy Clin I I up. Allergy Clin Imai.2002.125442] workers in Singapore. Br J Dermatol 2005;153(5):954-959. [http://dx.doi.org/10.1111/j.1365-
work 2133.2005.06820.x]

13. Palosuo T, Antoniadou I, Gottrup F, Phillips P. Latex medical gloves: Time for a reappraisal. Int Arch Allergy Immunol 2011;156(3):234-246. [http://dx.doi.org/10.1159/000323892]

Accepted 15 July 2014. 